\title{
The Legal Aspect of Cancellation of a Marriage Due To Formed Identity (Case of Decision Number 586 / PDT.G / 2014 / PN. JAKSEL)
}

\author{
Riki Afri Rizki ${ }^{1}$, Sriono $^{2}$, Risdalina ${ }^{3}$ \\ 1,2,3 Law Study Program, Faculty of Law, Labuhanbatu University, Indonesia \\ Sriono.mkn@gmail.com
}

\begin{abstract}
This article examines the legal aspects of the cancellation of marriage due to identity forgery based on the case of the South Jakarta District Court Decision Number 586 / PDT.G / 2014 / PN.JAKEL, this is regulated in Law number 1 of 1974 concerning Marriage. This research uses normative juridical research, which refers to the provisions of positive laws and regulations in Indonesia among the laws and regulations on Marriage by knowing the procedures of the marriage law and making it a guide in resolving problems in society. The results of the study found indicators of legal aspects between husband and wife that arise because of marriage between them. AThere are different nationalities, so that it becomes a study of International Civil Law and mixed marriage problems in Indonesia between Jessica Iskandar and Ludwig Frans Willibald regarding the validity of the marriage certificate so that it can be canceled and legal consequences after marriage cancellation. So there are important things that need to be considered if there is someone foreigners or non-citizens of Indonesian citizens who will conduct a mixed marriage with an Indonesian citizen. The marriage procedure is regulated in the Implementation Regulation of the Marriage Law, namely Government Regulation No. 9 of 1975 So that there are important things that need to be considered in the applicable marriage law, it should be known about the legal aspects and legal consequences according to the legal aspects in Indonesia.
\end{abstract}

Keywords

marrige; Identity forgery; legal consequences

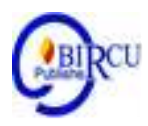

\section{Introduction}

Marriage that occurs between a man and a woman has physical and mental consequences both on the families of each community and also on the assets acquired between them both before and forever the marriage takes place. Marriage according to Law Number 1 of 1974 concerning Marriage (hereinafter referred to as the Marriage Law), is not only a civil act, but also a religious act, because the measure of whether a marriage is legal or not is entirely in the laws of each religion. and his beliefs.

The provisions of Article 2 paragraph (1) of the Marriage Law explain that "Marriage is legal if it is carried out according to the law of each religion and belief". This provision describes the principle of the Indonesian nation's marriage which is based on Pancasila, which can be seen from the explanation of Article 2 paragraph (1) of the Marriage Law that a marriage carried out according to their respective religions is the main principle of a legal marriage. Article 2 paragraph (2) of the Marriage Law states: "every marriage is recorded according to the prevailing statutory regulations". The validity of a marriage according to the Marriage Law is based on the religious law and beliefs of each, so that since the enactment of this Marriage Law, the marriage ceremony according to 
religious law has the character of determining whether the marriage is valid or not. (K. Wantjik Saleh , 1982). This resulted in many people not registering at the civil registry office. Based on the general explanation of the Marriage Law, regarding marriage registration, birth registration, death registration is an important event not a legal event. Registration of marriage in a certificate constitutes a marriage certificate. A marriage certificate is proof of marriage and is a perfect proof of the existence of marriage.

The procedures for marriage in Indonesia are varied from one another because in Indonesia it recognizes that there are various religions and beliefs, which have different procedures. This is possible in the Republic of Indonesia which is based on Pancasila which firmly recognizes the principle of religious freedom (Subekti, 2002). In society, there are many problems with this marriage law, there are those who only marry in religion but are not recorded and there are also legal problems in marriages that are only registered but not carried out through a religious ceremony. This is clearly not in accordance with the Marriage Law which regulates the validity of a marriage. The marriage procedure is regulated in the Implementation Regulation of the Marriage Law, namely Government Regulation No. 9 of 1975. In this Government Regulation concerning marriage procedures regulated in Article 10 paragraph (2), it is stated that "the marriage procedure is carried out according to the law of each religion and belief". In paragraph (3) it is stated that " With due observance of the marriage procedure according to the respective religious laws and beliefs, the marriage shall be carried out in front of a registrar and attended by two witnesses". (Perpu Number 9 of 1974).

The marriage agreement is a means to protect the assets of the bride and groom. Through this agreement the parties can determine their respective assets. Has there been a separation of assets in marriage from the beginning or is there joint assets, but the method of distribution is arranged in the event of a divorce. (Sriono, 2015). Meanwhile, the negative impact of children born from marriages whose marriage is not registered in the State administration is that children do not get inheritance rights from their father and father's family because children outside of marriage only have a relationship with the mother and their mother's family, while those who have inheritance rights from their father are only children who were born in a marriage that is legal according to the law (Risdalina, 2015). In the Marriage Law Book, the Compilation of Islamic Law, it explains the cancellation of a marriage according to the Marriage Law, namely "A husband or wife can apply for a marriage cancellation if at the time of the marriage there is fraud or misunderstanding regarding the husband or wife". It can be concluded from the description above that the cancellation of a marriage is due to fraud or falsification of identity in the legal conditions of a marriage that violates the law.

Case in decision No. 586 / PDT.G / 2014 / PN.JAKSEL a petition for cancellation perkawina $n$ filed ludwig fransz Willibald Against jessica iskandar. The applicant and the defendant were married on January 8, 2011. In connection with the issue of the marriage certificate number 05 / A1 / 2014 issued by the South Jakarta civil registry, according to Ludwig, his marriage was not yet valid according to religion, Ludwig had never made a marriage blessing with Jessika Iskandar at the True Jesus Church in Central Jakarta with the Christian Religion ( Ludwig's religion is Catholic and Ludwig felt that he had never converted to Christianity but married in a Christian manner), however, Jessika Iskandar visited Disdukcapil (Department of Population and Civil Registration) DKI Jakarta with requirements for marriage registration and also brought a blessing letter from the True Jesus Church. Central Jakarta by letter number 013 / GYS / jkt / VI / 14. From the letter, there was information that Jessica and Ludwig had been blessed on December 11, 2013, then a few months later the True Jesus Church denied that the church had never given a 
marriage blessing to Jessica and Ludwig at that time. The church did not feel that they had blessed the marriage and it turned out that the pastor who was claimed by Jessica Iskandar to do the blessing was in fact fictitious, there was no list of pastors recorded in the True Jesus church. The case of the marriage annulment lawsuit filed by Ludwig to Jessica is included in the case of International Civil Law, because there are foreign elements in the form of personal factors, namely citizenship status where Ludwig is a German citizen while Jessica is an Indonesian citizen. Their marriage took place in Indonesia. Where this case is about acts against the law (Article 1365 KUHPerdata "Every act that violates the law and brings harm to others, obliging the person who caused the loss due to his mistake to compensate for the loss"). What Jessica did was in the form of making a marriage certificate based on false documents.

Based on the description above, the author wants to examine the legal aspects of Marriage Cancellation due to Identity Falsification based on the marriage case of Jessica Iskandar and Ludwig Frans Willibald in the perspective of applicable law.

\section{Research Methods}

The research method used in this research is to use the normative juridical method, which refers to the provisions of positive laws and regulations in Indonesia, among the laws and regulations on Marriage by knowing the procedures for the law of marriage and making it a guide in resolving existing problems. in society. In this study refers to secondary data research. Thus there are main activities that will be carried out in carrying out this research, namely library research, which is obtained through literature, by reviewing, analyzing, and managing the literature on legislation by researching through articles related to the problem to be examined. ( Soerjono Soekanto \& Sri Mahmudji, 2003).

\section{Discussion}

\subsection{Legal Balance Used by Judges to Decide Cases Number: 586 / PDT.G / 2014 / PN. JAKSEL}

Article 22 of Law Number 1 of 1974 concerning Marriage states that: "A marriage can be annulled if the parties do not meet the requirements for a marriage." According to the contents of Article 22, a marriage which is carried out without fulfilling the requirements stipulated by Law Number 1 of 1974 concerning Marriage as mentioned in Article 6 to Article 12 concerning the conditions of marriage, can be requested for cancellation of the marriage. (CST Kancil, 1989). The right to request the annulment of a marriage is only given to certain people. This person can exercise his right to ask for the annulment of a marriage, but otherwise the marriage can continue legally. (Ali Afandi, 1986).

The legal considerations used by the Judge to decide the marriage annulment case are as follows:

1) Considering, the marriage annulment trial between Jessica Iskandar and Franz Ludwig has reached its final point. The panel of judges at the South Jakarta Religious Court decided that the marriage of the two men was officially canceled under the State Law. The head of the panel of judges, Made Sutrisna, said that the marriage that Jessica admitted had been officially carried out by the State, apparently had a disagreement with the existing facts. There are 10 unsynchronized Marriage Certificate (SKP). 
2) Considering that the main problem is that the SKP of the Church should be in Central Jakarta, but those listed in the SKP are located in West Jakarta.

3) Considering, whereas the Main Problem in the Pekara There are differences in the shape and type of letters stated in the Marriage Certificate (SKP).

4) Considering that the subject matter is that the plaintiff (Ludwig) and the defendant (Jessica) have never been registered in the church in question. And never do the Blessing by the Pastor in question. However, a marriage certificate dated January 8, 2011. Which is a fake marriage certificate and violates the applicable law.

5) The panel of judges also found that there were stamps and signatures on their marriage certificates.

It can be concluded by the author that the verdict handed down by the judge was correct, the judge had considered the decision carefully. Regarding the sentence or legal considerations, describing how the Judge qualifies the facts or events, the Judge's assessment of the facts submitted, the Judge considers chronologically and in detail on each of its contents. Judges also establish legal bases used by judges in assessing facts and deciding cases, both written law and unwritten law.

\subsection{Legal Consequences for the Cancellation of a Marriage That Has Been} Terminated By the Court

\section{a. Legal Effects on Children}

Regarding the position of the child as a result of the cancellation of the marriage, Article 28 paragraph (2) letter (a) of Law Number 1 of 1974 concerning Marriage states that the decision to annul a marriage does not apply retroactively to children born from the marriage. The annulment of a marriage will not break the legal relationship with both parents even if the marital relationship of the parents is broken. The child has the right to inherit from his parents and both parents have the obligation to care for and educate the child. Children born in a marriage that has been canceled do not apply retroactively, so that the child is still considered the legal child of both parents, even though the parent's marriage has been canceled by the Religious Court.

\section{b. Legal Consequences Consume Assets Obtained During the Marriage Period}

Regarding the position of joint assets in the cancellation of marriage case number 586 / PDT.G / 2014 / PN.JAKSEL, there is no mention of the issue of distribution of marital assets. The legal consequences of a marriage cancellation on joint assets are contained in Article 28 paragraph (2) letter b of Law Number 1 of 1974 concerning Marriage which states that the husband or wife acts in good faith, except for joint assets, if the marriage is annulled in based on the existence of other previous marriages. Joint assets as a result of the cancellation of marriage in that case are deemed non-existent. The marriage has been canceled since it was canceled and the joint property automatically becomes canceled and it is assumed that there was never any joint property. Assets that are retroactive are joint assets because there was another marriage that took place earlier, so as a result of the marriage law, joint assets do not exist, as explained in Article 28 paragraph 2 of the Marriage Law. 


\section{Conclusion}

Based on this description, the conclusions in this study can be drawn as follows:

1. The legal consequences of a marriage cancellation are firstly it is not legally enforceable / null and void for the sake of the Marriage Certificate and Marriage Certificate Quote Number 05 / A1 / 2014 and secondly, the assets are still controlled by each party.

2. The legal effort to settle a marriage due to identity falsification is the annulment of the marriage because it has committed a criminal offense and has caused losses to many parties.

3. The basis for the judge's consideration in deciding the cancellation of the marriage due to falsification of identity in case number 586 / PDT.G / 2014 / PN.JAKSEL was because the Defendant had faked his identity by claiming to have performed blessing or baptism at the True Jesus Church, Central Jakarta.

As for some suggestions that can be delivered based on the discussion, among others:

1. Suggestions for legal consequences are to protect victims of marriage fraud, and severely punish those who falsify their identity for the sake of marriage, because this is very detrimental, not only to the victim but to his family, as well as to other material and non-material losses.

2. Suggestions for completing a marriage due to identity forgery are that the marriage must be canceled because it is detrimental to other parties who may really want to build a household with the other party, but are disappointed because that party faked himself and deceived him and his extended family.

3. The Panel of Judges in deciding cases regarding the cancellation of a marriage, must also decide on the fate of the child resulting from a canceled marriage such as the determination of the guardian of the child, as well as the obligation to care for the child resulting from a canceled marriage, thus the rights of children born from a canceled marriage. will be more secure and protected by applicable law.

\section{References}

Ali Afandi, Hukum Waris Hukum Keluarga Hukum Pembuktian Menurut Kitab UndangUndang Hukum Perdata (BW), Jakarta, PT Bina Aksara, (1986).

K. Wantjik Saleh, Hukum Perkawinan Indonesia, Jakarta Timur, Ghalia Indonesia , (1982). Soerjono Soekanto dan Sri Mahmudji, Penelitian Hukum Normatif, Suatu Tinjauan Sinkat, Jakarta. Raja Grafindo Persada, (2003).

Subekti, Hukum Keluarga dan Hukum Waris, Penerbit PT. Intermasa , (2002).

Buku Hukum Perkawinan Kompilasi Hukum Islam, Penerbit. Fokus Media

C. S. T. Kansil, Pengantar Ilmu Hukum dan Tata Hukum Indonesia, Jakarta, Balai Pustaka, 1989.

Sriono . Fungsi Perjanjian Kawin Terhadap Perkawinan Menurut Undangundang Nomor 1 Tahun 1974 Tentang Perkawinan . Jurnal Ilmiah "Advokasi" Vol. 03. No. 02. September 2015 .

Kitab Undang - Undang Hukum Perdata \& Undang-Undang Nomor 1 tahun 1974 tentang perkawinan. Peraturan Pemerintah No. 9 Tahun 1975 tentang Tatacara Perkawinan.

Hasil Putusan Pengadian Neggeri Jakarta Selatan No. 586/PDT.G/2014/PN.JAKSEL

Artikel Kasus Kronologi Pernikahan Jesica dan Ludwig https://www.liputan6.com/showbiz/read/2130803/ini-kronologi-pernikahan-fiktifjessica-iskandar-ludwig . 
Artikel Paripuan Putusan Hakim membatalkan pernikahan jesika Ludwig https://www.tribunnews.com/seleb/2015/10/15/ini-alasan-hakim-batalkanpernikahan-jessica-iskandar-dengan-ludwig

Risdalina . Perlindungan Hukum Terhadap Anak Dari Perkawinan Yang Tidak Dicatatkan Dalam Perspektif Hukum Administrasi Negara . Jurnal Ilmiah "Advokasi” Vol. 03. No. 02. September 2015 . 